\title{
„Ikona” - wystawa w kaplicy byłego greckokatolickiego seminarium w Przemyślu
}

\author{
„Ikona rzeczywiście spada z nieba. \\ Jeśli nie jest nam to dane z góry, $w$ ogóle nie powstanie". \\ Jerzy Nowosielski, 1984
}

W

przeddzień obchodów uroczystości 25-lecia utworzenia Metropolii Przemysko-Warszawskiej Obrządku Greckokatolickiego oraz podniesienia Diecezji (Eparchii) Przemyskiej do godności Archidiecezji (Archieparchii) Przemysko-Warszawskiej, 6 lipca 2021 r. odbyło się otwarcie wystawy „Ikony”. Głównym jej organizatorem była Archidiecezja Przemysko-Warszawska Kościoła Greckokatolickiego w Polsce, przy współpracy Archidiecezjalnej Komisji Konserwatorskiej, Przemyskiej Szkoły Ikonopisania - Fundacji STRYWIHOR, Pracowni Sztuki Sakralnej IKOS, Stowarzyszenia Młodzieży Greckokatolickiej SAREPTA, Stowarzyszenia Przyjaciół Nowicy.

Miejsce wystawy - kaplica dawnego Seminarium Greckokatolickiego przy ul. Basztowej 13 w Przemyślu - nie jest przypadkowe, bo można tam podziwiać zachowane, oryginalne malarstwo ścienne w tamburze i kopule nawy kaplicy.

Ideą wystawy - jak mówi dr Eugeniusz Zawałeń, archidiecezjalny konserwator zabytków i kurator wystawy - jest przedstawienie dorobku artystycznego ostatniego 25-lecia naszej Archidiecezji, spadkobierczyni Greckokatolickiej Diecezji Przemyskiej. Przybliżamy szerokiej publiczności mało znane, ale żywe i intrygujące malarstwo ikonowe.

Wystawę podzielono na cztery kręgi tematyczne:

- Ikony historycznej Eparchii Przemyskiej (z zasobów Archidiecezji Przemysko-Warszawskiej).

Można tu zobaczyć m.in.: Carskie wrota, ikony Chrystus nauczający i Bogurodzica, Krucyfiks oraz projekty koncepcyjne ikonostasu, który miał być zainstalowany $\mathrm{w}$ tej kaplicy.

- Prace poplenerowe z Nowicy, z zasobów Bractwa Cerkiewnego „Sarepta” w Krynicy Zdroju i Towarzystwa Przyjaciół Nowicy.

Są to prace doświadczonych współczesnych artystów, ikonopisarzy z Polski i Ukrainy, jak Roman Vasyłyk, Danyło Mowczan, Timur Karim. Twórcze spojrzenie na ikonę, zakorzenione w tradycji, a zarazem otwarte na współczesne środki artystycznego wyrazu, pozwala odczytywać jej aktualność. Jest ona nadal nośnikiem treści chrześcijańskiej wiary, wyrażanej w sposób oryginalny, istotowy, przemawiającej także do współczesnego człowieka.

- Prace uczestników Przemyskiej Szkoły Ikonopisania, która działa przy Fundacji Odrodzenia, Badań i Rozwoju Dziedzictwa Kulturowego Ziemi Przemyskiej „Strywihor”. 
Pod czujnym okiem pań: Nadiji Karwackiej - prezesa Fundacji, a jednocześnie ikonopisa, teoretyka i wykładowcy Ukraińskiego Katolickiego Uniwersytetu we Lwowie, oraz Wiry Brodowicz - dyrektor generalnej Zarządu Fundacji, uczestnicy szkoły posługują się dawnymi technikami ikonopisania, naśladując arcydzieła sztuki sakralnej, począwszy od XIV aż do XVI wieku. Kontynuują tradycje ikonopisania, wzorując się na ikonach znajdujących się w muzeach Polski, Ukrainy i Słowacji, pochodzących z terenu historycznej Eparchii Przemyskiej, której początek datuje się na XII wiek. Lokalne ikony z tego okresu są świadectwem niepowtarzalnej szkoły ikonopisarskiej, której wyjątkowość polega na połączeniu bizantyjskiego dziedzictwa z miejscową tradycją.

- „Ikony - Cienie” Małgorzaty Dawidiuk z autorskiej pracowni IKOS w Przemyślu.

Małgorzata Dawidiuk jest absolwentką Akademii Sztuk Pięknych im. Ilii E. Riepina w Petersburgu. Ukończyła Wydział Malarstwa i Konserwacji - specjalizacja ikona. Jest autorką wielu dzieł sakralnych w Polsce: ikon, ikonostasów, polichromii, a także współrealizatorką malowideł ściennych w Kaplicy Sanktuarium Miłosierdzia Bożego w Łagiewnikach. „Ikony-Cienie” Małgorzaty Dawidiuk powstają na szczątkach ikon i deskach cerkiewnych. Dzisiaj popękane, niegdyś poświęcone deski noszą w sobie cień sakralności, obok którego autorka nie przechodzi obojętnie. Prace te pobudzają wyobraźnię widza. Są mistyczne, przejmujące i pozostawiają miejsce na indywidualną interpretację.

Wystawa pozwala podziwiać ikony pisane-malowane według ściśle ustalonych kanonów, jak również takie, w których tradycja, wywodząca się z obu obrządków liturgicznych, konfrontuje się z osobistym doświadczeniem twórców.

Połączenie tradycji kanonu ikonograficznego i przeżywanie treści przedstawień malarskich rodzi dzieła otwarte na każdego człowieka.

Ekspozycja pomaga widzowi osiągnąć wewnętrzny spokój oraz harmonię w poszukiwaniu duchowości we współczesnym świecie. Zmusza do zatrzymania się w zadumie tu i teraz...

Maria Ficak

ORCID 0000-0003-0142-2566

DOI:10.30657/pha.33.2021.25

(Zespół Szkół Ogólnokształcących nr 2 im. Markiana Szaszkewicza w Przemyślu) e-mail:mficak19@gmail.com 


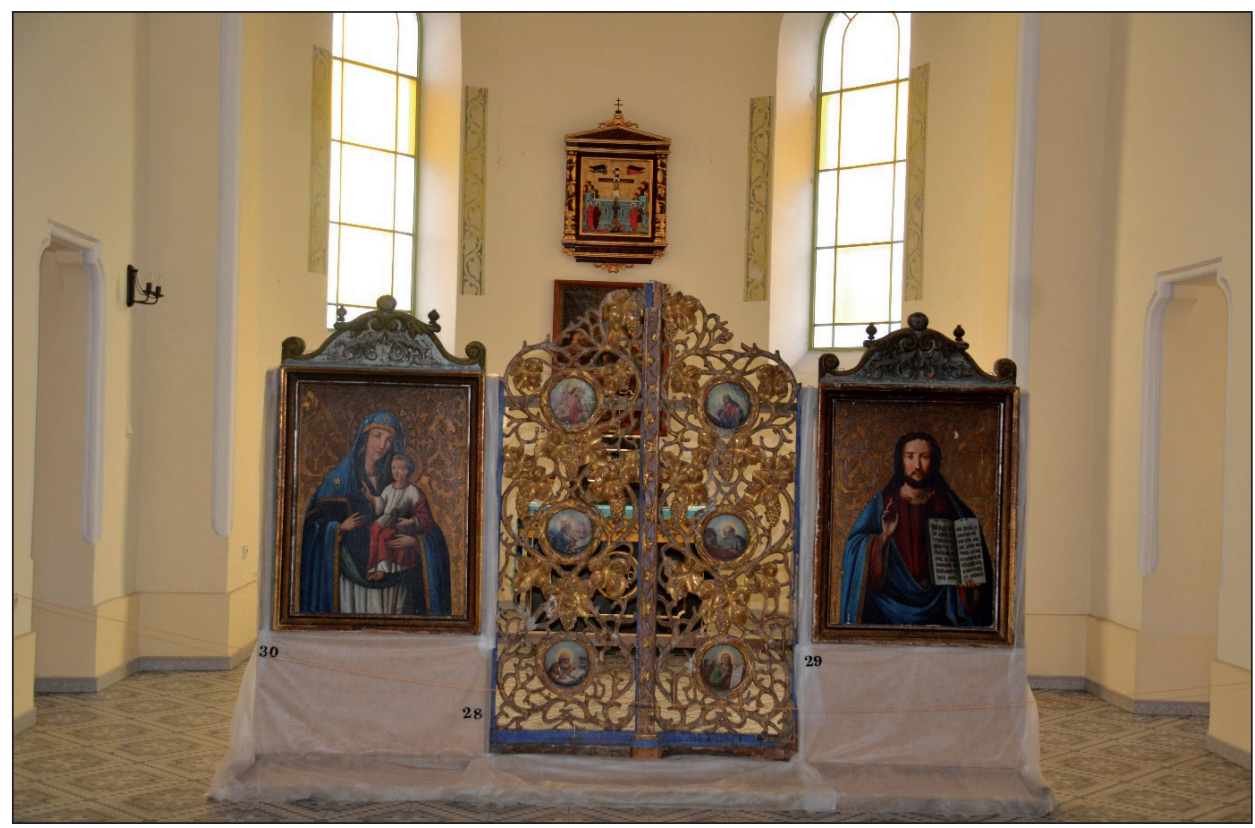

Carskie Wrota, Chrystus Nauczający i Bogurodzica z historycznej Eparchii Przemyskiej.

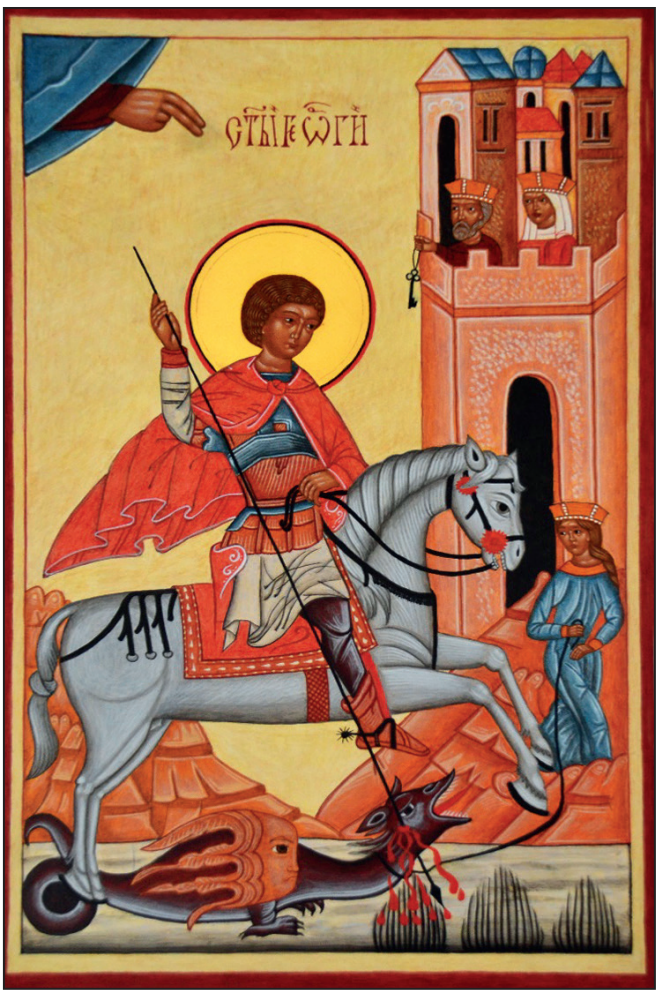

Święty Jerzy Męczennik „Zwycięzca”, XVI w., z cerkwi w Wełykiem. Miejsce ekspozycji: Muzeum Narodowe Ziemi Przemyskiej w Przemyślu. 


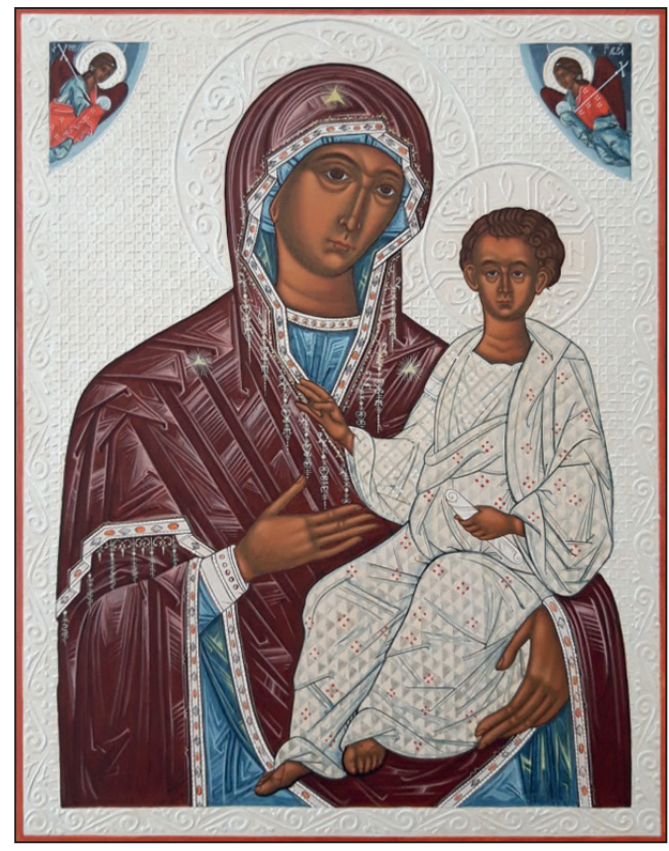

Hodegetria $w$ otoczeniu archaniołów, XVI w., Krąg Mistrza ikonostasu cerkwi w Nakonecznem. Miejsce ekspozycji: Muzeum Narodowe w Krakowie.

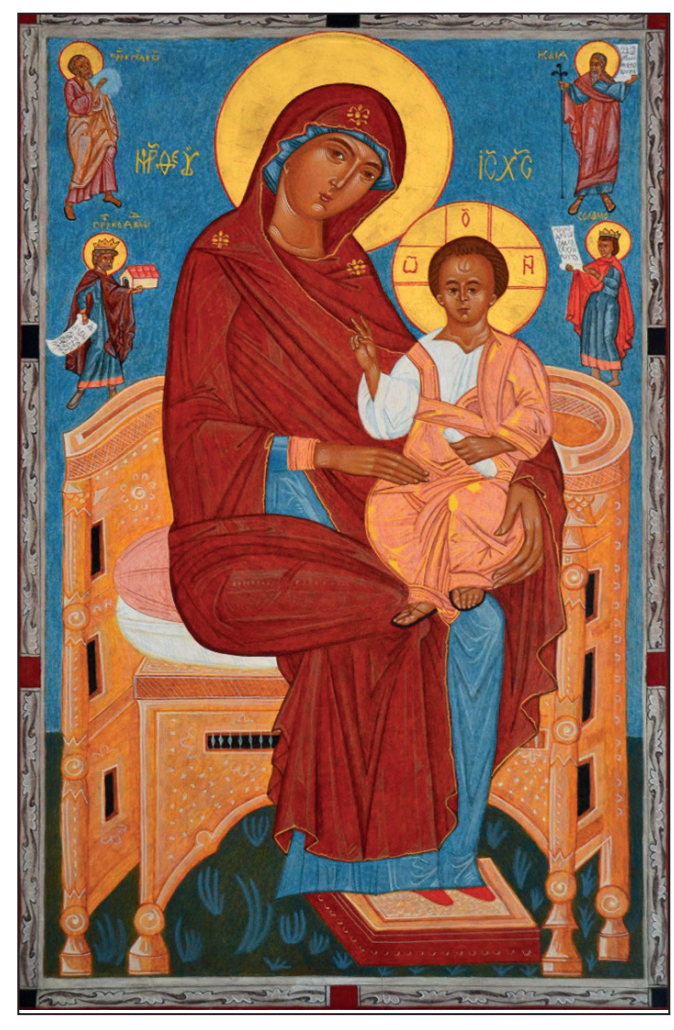

Hodegetria na tronie $w$ otoczeniu proroków i królów starotestamentowych, XV-XVI w., z cerkwi w Krempnej. Miejsce ekspozycji: Muzeum Narodowe im. Andrzeja Szeptyckiego we Lwowie. 


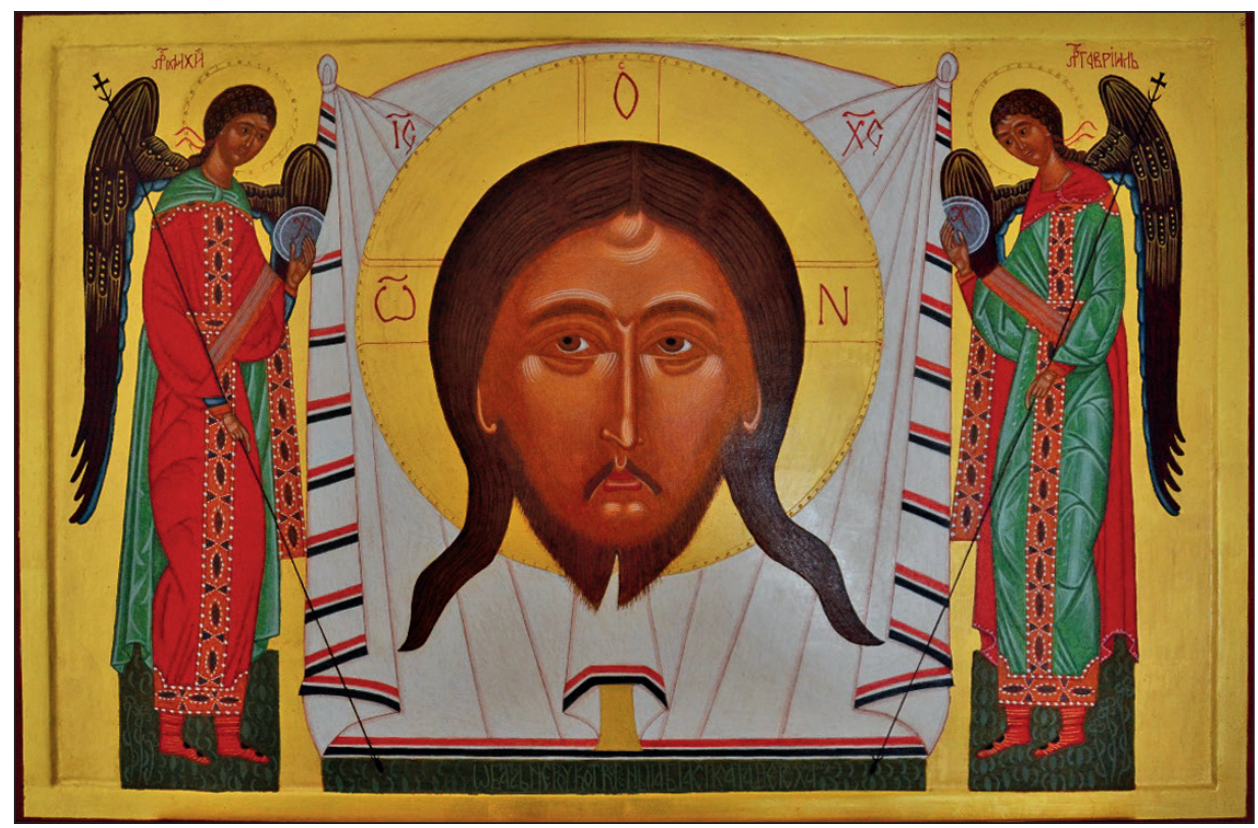

Mandylion - Oblicze Chrystusa na chuście, XV w., z cerkwi we wsi Terło. Miejsce ekspozycji: Muzeum Narodowe im. Andrzeja Szeptyckiego we Lwowie.

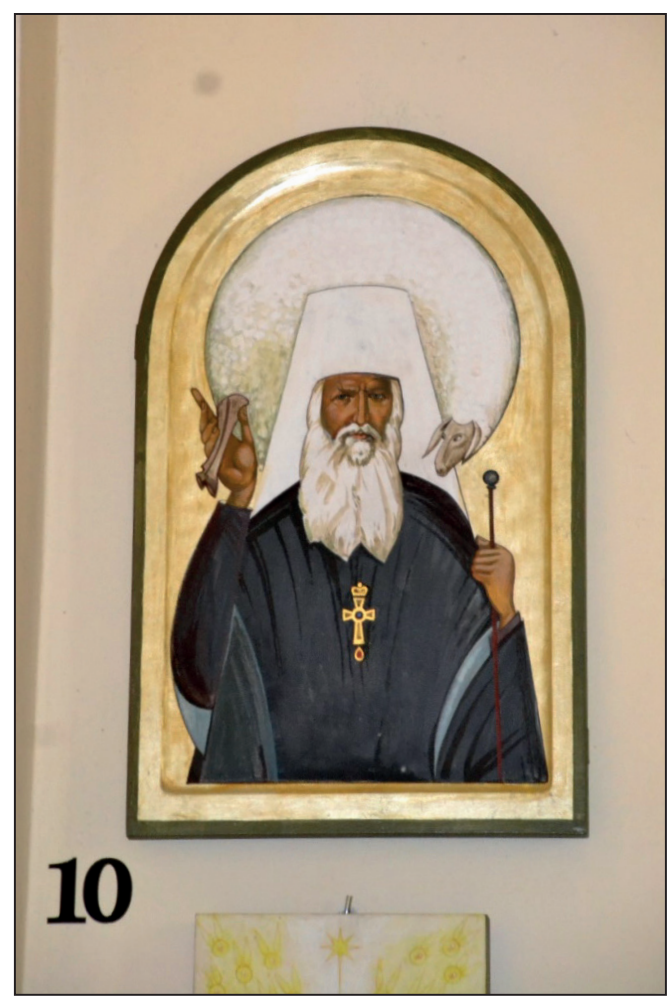

Dobry Pasterz - Roman Vasylyk, 2015. 


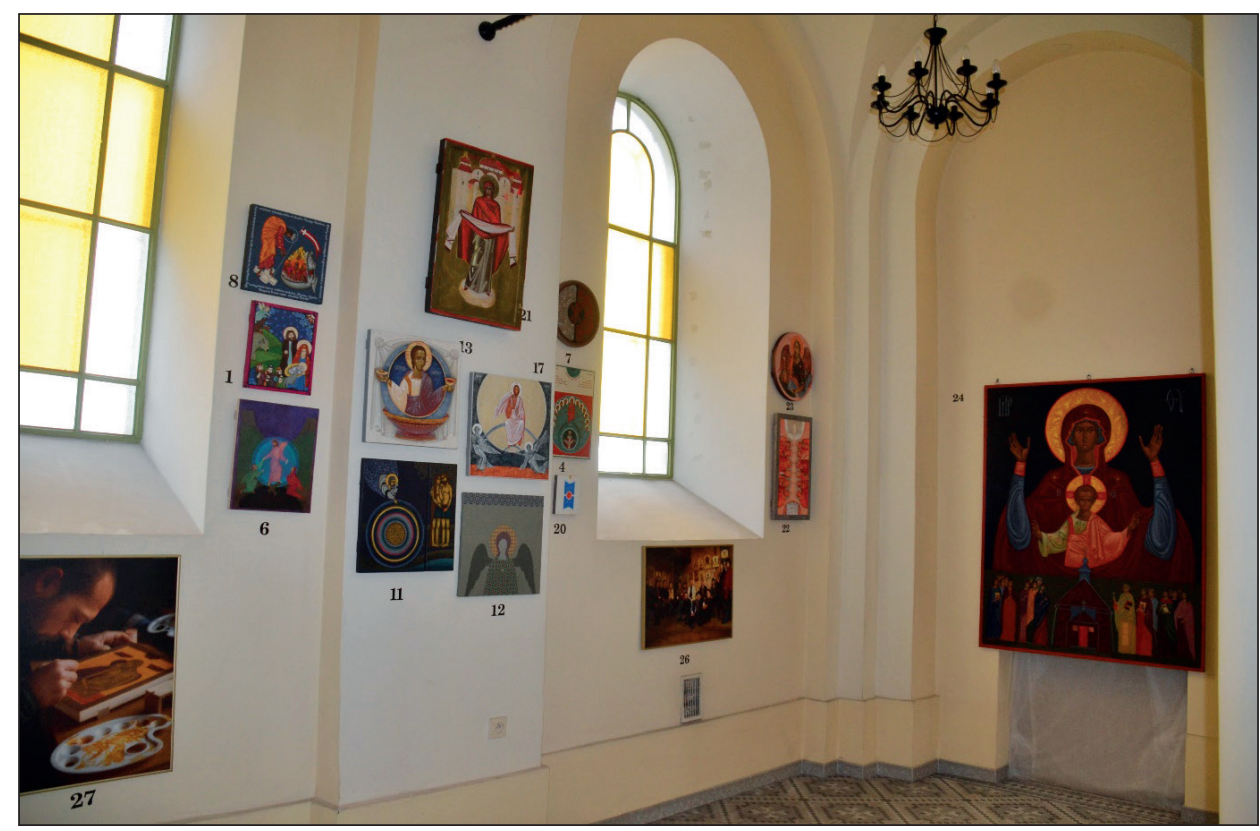

Prace poplenerowe z Nowicy na przemyskiej wystawie w 2021 r.

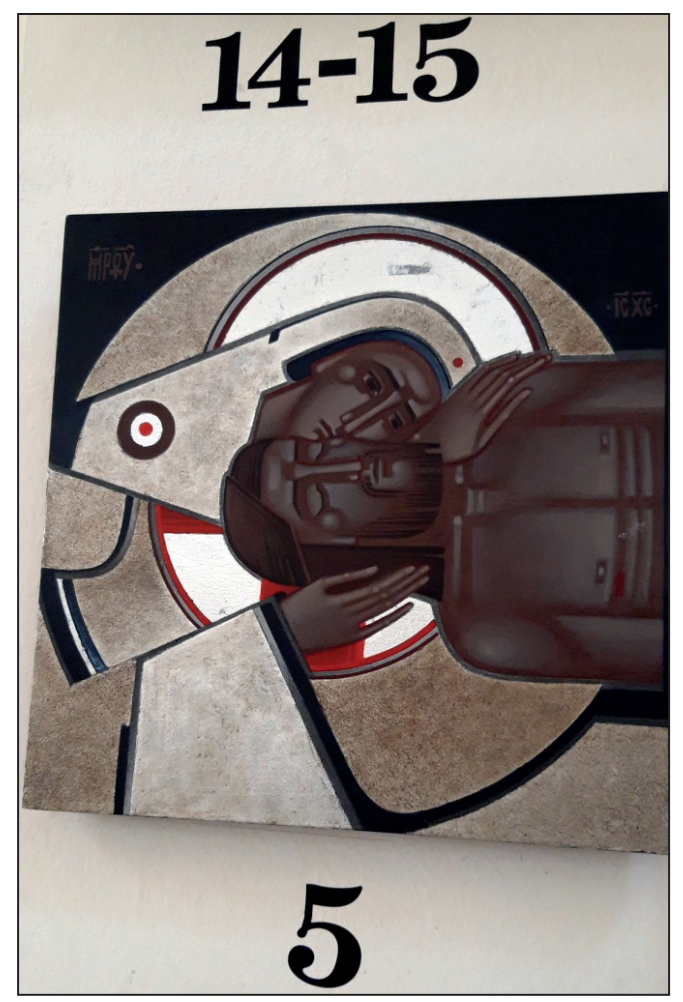

Opłakiwanie - Olha Horodyska, 2017. 


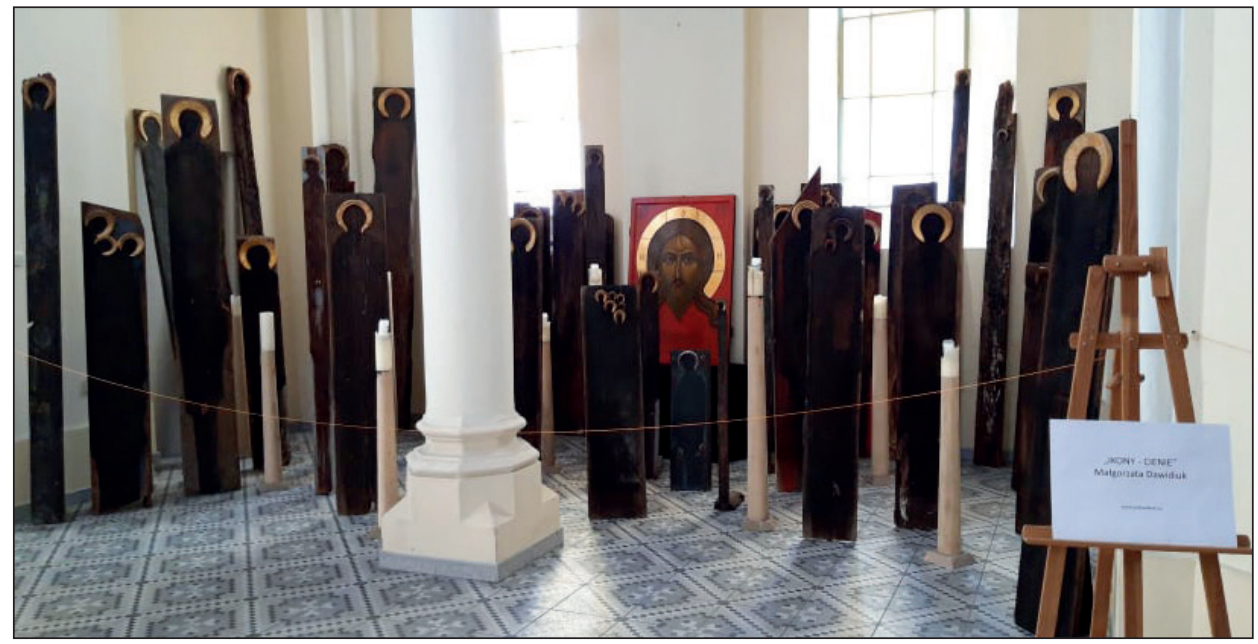

Ikony - Cienie - Małgorzata Dawidiuk, Przemyśl.

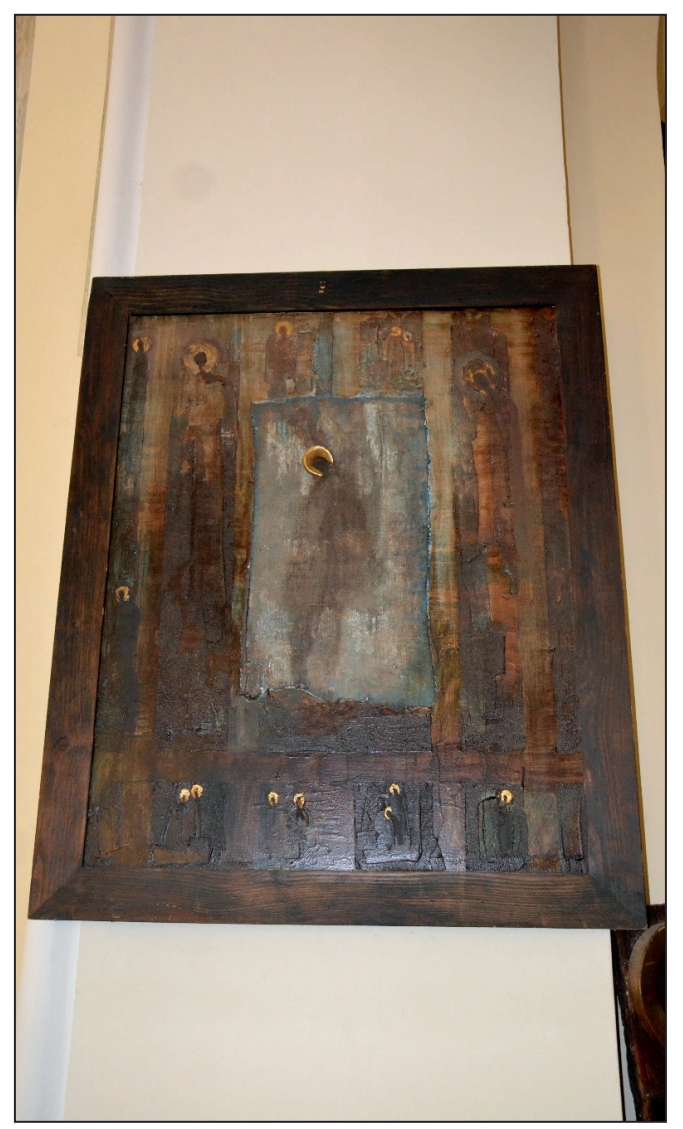

Z cyklu: Ikony - Cienie - Małgorzata Dawidiuk, Przemyśl. 


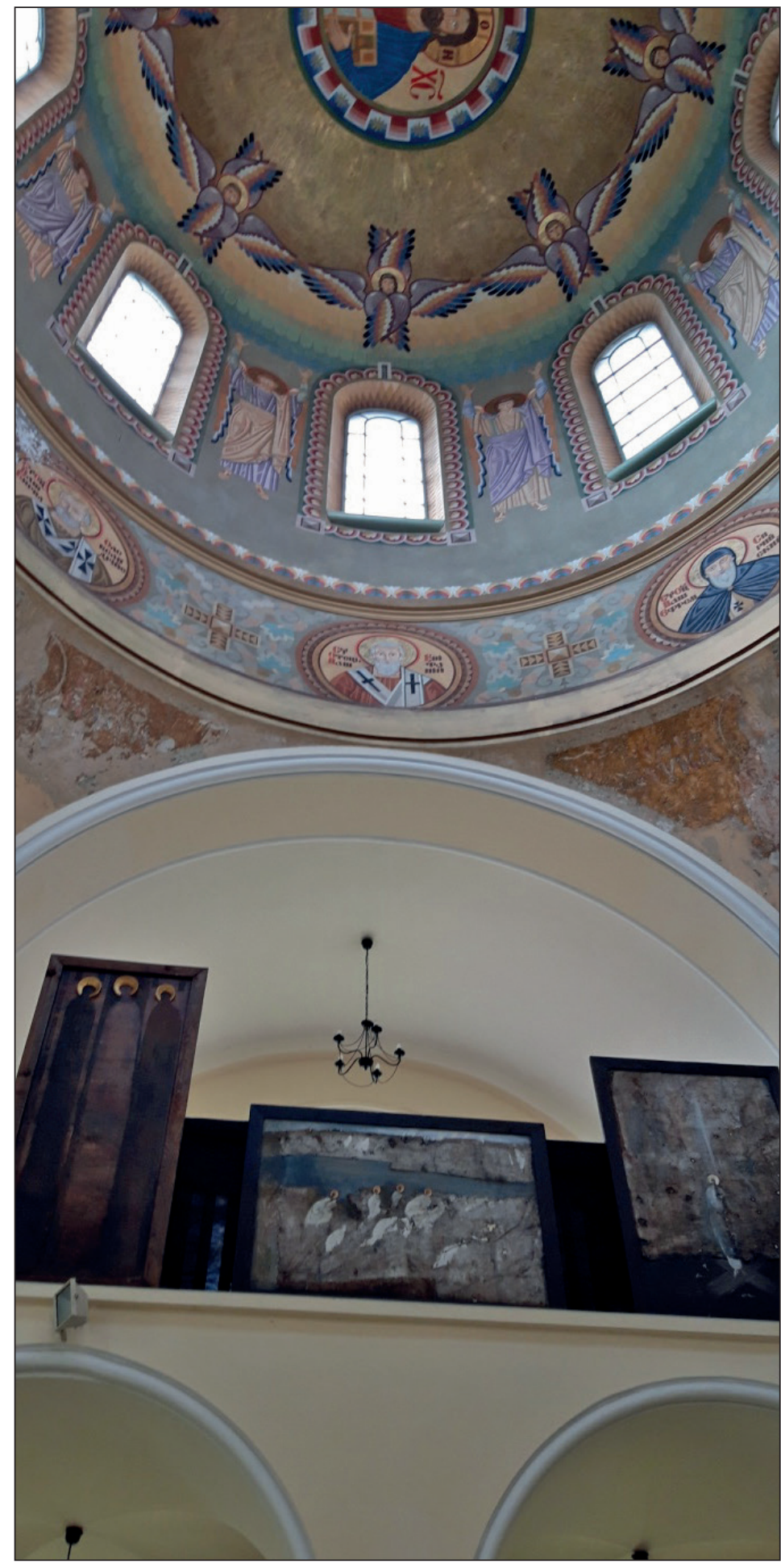

Malarstwo ścienne w tamburze i kopule kaplicy dawnego Seminarium Greckokatolickiego w Przemyślu. 


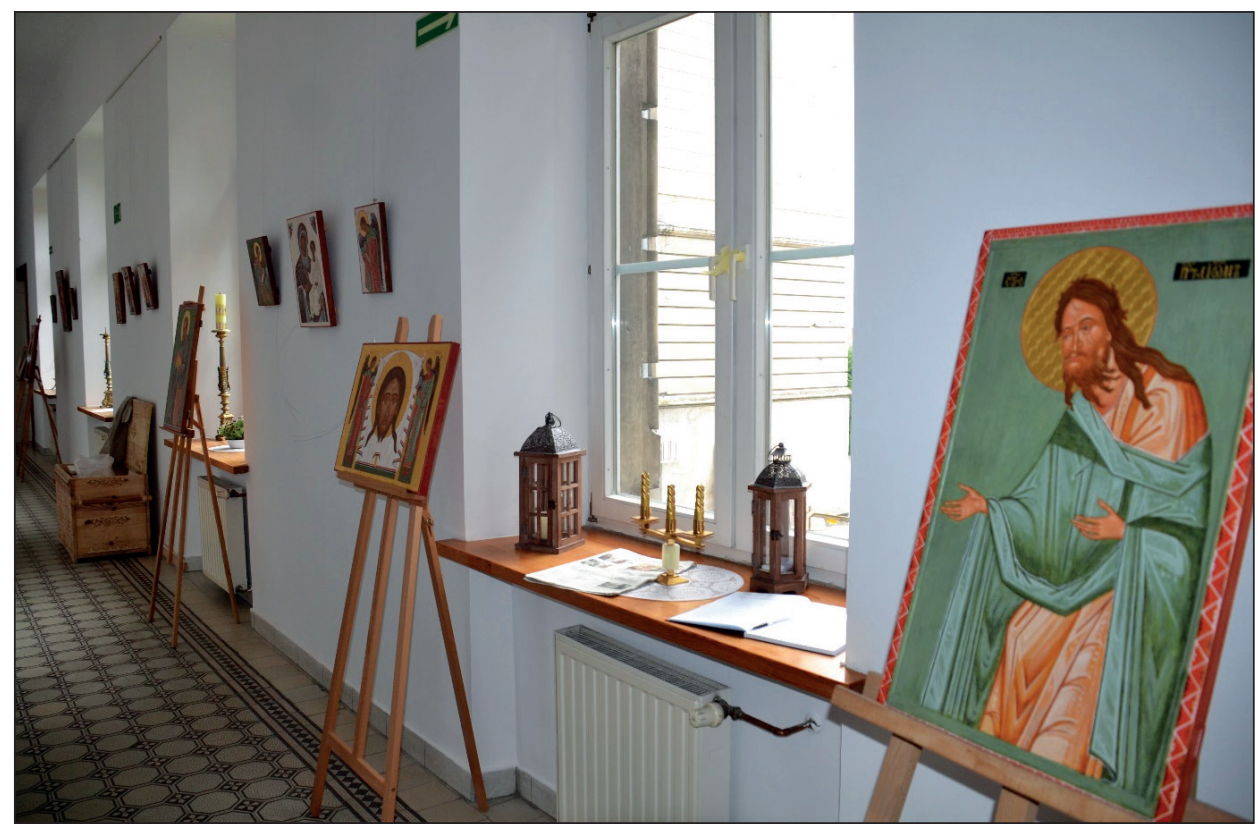

Fragment wystawy - na pierwszym planie Ikona św. Jana Chrzciciela z cerkwi w Drohobyczu. Miejsce ekspozycji: Zamek w Olesku, Ukraina.

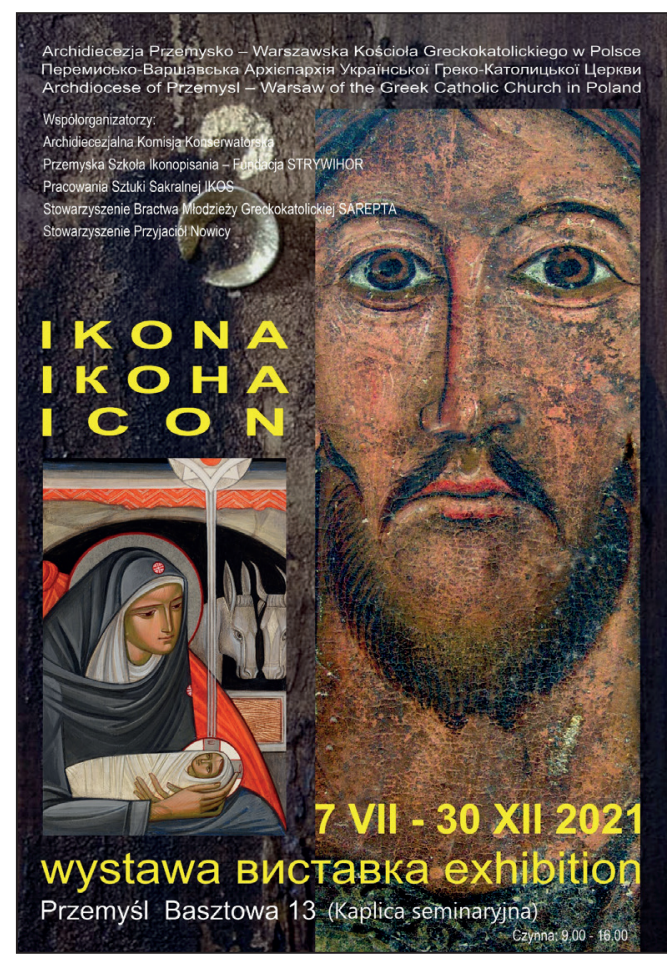

Plakat informujący o wystawie ikon Archidiecezji Przemysko-Warszawskiej Kościoła Greckokatolickiego w Polsce. 